\title{
Problemas Clínicos Pré-Anestésicos de Pacientes Morbidamente Obesos Submetidos a Cirurgias Bariátricas: Comparação com Pacientes Não Obesos *
}

\section{Preanesthetic Clinical Problems of Morbidly Obese Patients Submitted to Bariatric Surgery: Comparison with Non-Obese Patiens}

Getúlio Rodrigues de Oliveira Filho, TSA ${ }^{1}$, Tânia Helena Carnieleto Nicolodi ${ }^{2}$, Jorge Hamilton Soares Garcia, TSA ${ }^{3}$, Marcos Antônio Nicolodi, TSA ${ }^{3}$, Ranulfo Goldschmidt, TSA ${ }^{3}$, Adilson José Dal Mago ${ }^{3}$

\begin{abstract}
RESUMO
Oliveira Filho GR, Nicolodi THC, Garcia JHS, Nicolodi MA, Goldschmidt R, Dal Mago AJ - Problemas Clínicos Pré-Anestésicos de Pacientes Morbidamente Obesos Submetidos a Cirurgias Bariátricas: Comparação com Pacientes Não Obesos
\end{abstract}

Justificativa e Objetivos - A obesidade mórbida associa-se a problemas clínicos, responsáveis por diminuição da expectativa de vida. Pacientes obesos mórbidos são candidatos a cirurgias bariátricas, impondo novos desafios ao anestesiologista. Este estudo comparou a prevalência de problemas clínicos entre pacientes morbidamente obesos submetidos a cirurgias bariátricas e não obesos submetidos a outros procedimentos eletivos.

Método - Foram estudados, retrospectivamente, os registros eletrônicos de 2986 pacientes divididos em grupo 1, obesos mórbidos submetidos a cirurgias bariátricas e grupo 2, com indice de massa corporal menor que 30 , submetidos a outros procedimentos eletivos, relacionados ao grupo 1 pela idade, sexo e estado físico (ASA). Os problemas pré-anestésicos do grupo 1 foram pesquisados no grupo 2 e as prevalências comparadas. As razões de chance $(R C)$ e respectivos limites de $95 \%$ de confiança (LC 95\%) foram calculados.

Resultados - Os problemas identificados nos grupos 1 e 2 e suas respectivas prevalências foram: refluxo gastroesofágico $(16,67 \%$ e 0,48\%), hipertensão arterial sistêmica (50\% e $3,06 \%)$, diabete melito tipo II (6,25\% e 0,31\%), hipotireoidismo $(6,25 \%$ e $0,31 \%)$, asma brônquica $(10,42 \%$ e $1,43 \%)$ e pneumopatia restritiva $(10,42 \%$ e $0,03 \%)$. As prevalências foram significativamente mais altas no grupo 1. Foram ainda identificados, no grupo 1 , os seguintes problemas que não foram encontrados no grupo 2: epilepsia (2,08\%), esteatose hepática $(12,5 \%)$, colecistopatia calculosa $(6,25 \%)$, dislipidemia $(20,83 \%)$ e hipopituitarismo $(2,08 \%)$.

\footnotetext{
* Recebido dos (Received from) Hospitais de Caridade e Governador Celso Ramos, CET/SBA Integrado de Anestesiologia da SES-SC, Florianópolis, SC

1. Responsável pelo CET/SBA

2. Anestesiologista do Grupo de Cirurgia Bariátrica do Hospital de Caridade

3. Instrutor do CET/SBA
}

Apresentado (Submitted) em 03 de agosto de 2001

Aceito (Accepted) para publicação em 09 de outubro de 2001

Correspondência para (Mail to):

Dr. Getúlio Rodrigues de Oliveira Filho

Rua Luiz Delfino 111/902

88015-360 Florianópolis, SC

E-mail: grof@th.com.br

(c) Sociedade Brasileira de Anestesiologia, 2002
Conclusões - A prevalência de problemas clínicos é significativamente mais alta em pacientes portadores de obesidade mórbida do que em não obesos de mesma idade, sexo e estado físico.

UNITERMOS: AVALIAÇÃO PRÉ-ANESTÉSICA; CIRURGIA, Abdominal: bariátrica

\section{SUMMARY}

Oliveira Filho GR, Nicolodi THC, Garcia JHS, Nicolodi MA, Goldschmidt R, Dal Mago AJ - Preanesthetic Clinical Problems of Morbidly Obese Patients Submitted to Bariatric Surgery: Comparison with Non-Obese Patiens

Background and Objectives - Morbid obesity is associated to clinical problems responsible for decreased life expectancy. Morbidly obese patients are candidates to gastric bypass and pose new challenges to the anesthesiologist. This study compared the prevalence of clinical problems among morbidly obese patients submitted to bariatric surgery to non-obese patients submitted to other elective surgical procedures.

Methods - Electronic records of 2986 patients were retrospectively studied. Patients were divided in two groups; 1: patients with morbid obesity submitted to bariatric surgeries; and group 2: non obese patients (body mass index less than $30 \mathrm{~kg} \cdot \mathrm{m}^{-2}$ ), submitted to other elective surgical procedures. Groups were matched according to age, gender and ASA physical status. Preanesthetic problems common to group 1 were investigated in group 2, and prevalence was compared. Odds ratios and 95\% confidence limits were calculated.

Results - Clinical problems identified in groups 1 and 2 and their respective prevalence were: gastroesophageal reflux (16.67\% and $0.48 \%$ ), systemic hypertension (50\% and $3.06 \%$ ), type II diabetes mellitus $(6.25 \%$ and $0.31 \%)$, hypothyroidism (6.25\% and $0.31 \%)$, bronchial asthma (10.42\% and $1.43 \%)$ and restrictive lung disease $(10.42 \%$ and $0.03 \%)$. Incidences were significantly higher in group 1. Additionally, the following problems were found in group 1, but not in group 2: epilepsy (2.08\%), nonalcoholic fatty liver (12.5\%), gall bladder stones (6.25\%), dyslipemia (20.83\%) and hypopytuitarism (2.08\%).

Conclusions - The prevalence of clinical problems was significantly higher in morbidly obese patients as compared to their non-obese counterparts.

KEY WORDS - PREANESTHETIC EVALUATION; SURGERY: Abdominal: bariatric

\section{INTRODUÇÃO}

besidade mórbida é definida pelo índice de massa corporal elevado, ou seja, o resultado da divisão do peso em quilos pela altura em metros elevada ao quadrado, igual ou superior a $40 \mathrm{~kg} \cdot \mathrm{m}^{-2}$. Nas últimas décadas, sua prevalên- 
cia tem aumentado e, com isto, os gastos decorrentes do tratamento das doenças associadas, como hipertensão arterial, diabete melito, cardiopatia isquêmica e hipertensão arterial pulmonar. A expectativa de vida dos pacientes morbidamente obesos é significativamente menor do que a de não obesos. Para tais pacientes, a cirurgia é o único tratamento eficaz ${ }^{1}$. O conhecimento dos problemas associados à obesidade permite o aprofundamento da investigação dos sistemas mais freqüentemente afetados pela doença, durante a consulta pré-anestésica. O objetivo deste estudo foi o de identificar as doenças associadas à obesidade, detectadas na avaliação pré-anestésica de pacientes morbidamente obesos submetidos a cirurgias bariátricas e comparar sua prevalência em uma população não obesa.

\section{MÉTODO}

Com a aprovação da Comissão de Ética Médica do Hospital, foram revisados os registros eletrônicos da avaliação pré-anestésica de 2986 pacientes, divididos em: grupo $1(n=$ 48), morbidamente obesos, submetidos a cirurgias bariátricas e grupo $2(n=2938)$, com índice de massa corporal (IMC) menor que 30 , submetidos a outros procedimentos eletivos, relacionados aos pacientes do grupo 1 por idade, sexo e estado físico (ASA). Os problemas pré-anestésicos identificados do grupo 1 foram pesquisados no grupo 2 e as prevalências comparadas pelo teste do Qui-quadrado com correção de Yates e exato de Fisher. As razões de chance (RC) e respectivos limites de 95\% de confiança (LC 95\%) foram calculados a partir das respectivas tabelas de contingência. $O$ nível de significância foi estabelecido em $5 \%$.

\section{RESULTADOS}

Os grupos foram homogêneos quanto à idade e à altura. As freqüências do estado físico ASA II e do sexo feminino, o peso e o IMC foram significativamente maiores no grupo 1 (Tabela I).

Tabela I - Dados Demográficos

\begin{tabular}{|c|c|c|}
\hline & Grupo 1 & Grupo 2 \\
\hline Idade (anos) ${ }^{1}$ & $36,36 \pm 12,58$ & $36,06 \pm 11,61$ \\
\hline Peso $(\mathrm{kg})^{1}$ & $120,70 \pm 19,98$ * & $65,37 \pm 8,81$ \\
\hline Altura $(m)^{1}$ & $1,65 \pm 0,08$ & $1,66 \pm 0,08$ \\
\hline $\mathrm{IMC}\left(\mathrm{kg} \cdot \mathrm{m}^{-2}\right)^{1}$ & $43,77 \pm 5,70$ * & $23,63 \pm 2,69$ \\
\hline $\operatorname{Sexo}(M / F)^{2}$ & $8 / 40$ * & $1674 / 1264$ \\
\hline $\operatorname{ASA}(I / I I)^{2}$ & $11 / 37$ * & $1329 / 1609$ \\
\hline
\end{tabular}

1. Dados expressos como Média $\pm \mathrm{DP}$

2. Dados expressos como freqüência

${ }^{*} p<0,05$ entre os grupos

As doenças identificadas na avaliação pré-anestésica dos pacientes do grupo 1 que foram também encontradas no grupo 2 e suas respectivas prevalências foram: refluxo gastro- esofágico (16,67\% e 0,48\%), hipertensão arterial sistêmica ( $50 \%$ e $3,06 \%)$, diabete melito tipo II $(6,25 \%$ e $0,31 \%)$, hipotireoidismo $(6,25 \%$ e $0,31 \%)$, asma brônquica $(10,42 \%$ e $1,43 \%$ ) e pneumopatia restritiva $(10,42 \%$ e $0,03 \%)$ (Tabela II).

Tabela II - Problemas Clínicos: Comparação entre os Grupos

\begin{tabular}{|c|c|c|c|}
\hline Problema & Grupo 1 & Grupo 2 & $\mathrm{RC}(\operatorname{LC} 95 \%)^{2}$ \\
\hline Refluxo gastroesofágico (P/A) $^{1}$ & $8 / 40$ * & $14 / 1924$ & $\begin{array}{c}41,77 \\
(15,04 ; 113,93)\end{array}$ \\
\hline Hipertensão arterial (P/A) ${ }^{1}$ & $24 / 24$ * & $90 / 2848$ & $\begin{array}{c}31,64 \\
(16,16 ; 60,32)\end{array}$ \\
\hline Diabete melito tipo II (P/A) ${ }^{1}$ & $3 / 45$ * & 9/2929 & $\begin{array}{c}21,69 \\
(6,96 ; 91,47)\end{array}$ \\
\hline Hipotireoidismo (P/A) $^{1}$ & $3 / 45$ * & 9/2929 & $\begin{array}{c}21,69 \\
(6,96 ; 91,47)\end{array}$ \\
\hline Asma $(\mathrm{P} / \mathrm{A})^{1}$ & $5 / 43$ * & $42 / 2896$ & $\begin{array}{c}8,01 \\
(2,64 ; 22,51)\end{array}$ \\
\hline Pneumopatia restritiva (P/A) & $5 / 43$ * & $1 / 2937$ & $\begin{array}{c}341 \\
(37,57 ; 759,31)\end{array}$ \\
\hline
\end{tabular}

1. $P / A=$ presente/ ausente; dados expressos como freqüência

2. RC (LC 95\%) = Razão de chances (Limites de 95\% de Confiança)

${ }^{*}=p<0,05$ entre os grupos

Foram ainda identificados no grupo 1 os seguintes problemas que não foram encontrados no grupo 2: epilepsia $(2,08 \%)$, esteatose hepática $(12,5 \%)$, colecistopatia calculosa $(6,25 \%)$, dislipidemia $(20,83 \%)$ e hipopituitarismo $(2,08 \%)$.

\section{DISCUSSÃO}

Os critérios de seleção de pacientes para cirurgias bariátricas foram estabelecidos pela Federação Internacional para a Cirurgia da Obesidade e são os seguintes: índice de massa corporal superior a $40 \mathrm{~kg} \cdot \mathrm{m}^{-2}$, ou entre 35 e $40 \mathrm{~kg} \cdot \mathrm{m}^{-2}$ em pacientes com condições co-mórbidas tratáveis com a perda de peso, presença de obesidade por no mínimo cinco anos, falha de tratamento conservador, ausência de história de alcoolismo ou de problemas psiquiátricos graves, idade entre 18 e 55 anos e risco cirúrgico aceitável, determinado pela avaliação pré-operatória ${ }^{1}$.

O paciente obeso candidato a cirurgia de obesidade é submetido a avaliação multidisciplinar, incluindo nutricionista, enfermeira especializada, psicólogo ou psiquiatra e anestesiologista. O papel deste último é fundamental para a detecção de estados mórbidos coexistentes, orientação de exames complementares e consultas especializadas, visando a compensação de doenças coexistentes. Por esta razão, a consulta pré-anestésica é realizada com antecedência.

Neste estudo, a prevalência de refluxo gastroesofágico foi significativamente maior nos pacientes obesos. Embora a obesidade possa não contribuir para a existência de refluxo gastroesofágico ${ }^{2}$, existem evidências de que o peso e o índice de massa corporal relacionam-se diretamente com a presença desta condição ${ }^{3}$, provavelmente pela maior prevalência de hérnia hiatal ${ }^{4}$. Em $61 \%$ dos pacientes, foram observaVol. 52, No 2, Março - Abril, 2002 
das alterações manométricas do esôfago, que podem contribuir para anormalidades da sensação visceral em pacientes morbidamente obesos ${ }^{5}$. Pacientes com índice de massa corporal superior a $30 \mathrm{~kg} \cdot \mathrm{m}^{-2}$ apresentam chances de ocorrência de refluxo 2,8 $(1,7$ a 4,5) vezes maiores do que aqueles com IMC menor que $30 \mathrm{~kg} \cdot \mathrm{m}^{-2} 6$. A presença de refluxo gastroesofágico relaciona-se com a ocorrência de eventos críticos associados com a intubação traqueal ${ }^{7}$.

Hipertensão arterial sistêmica foi observada em $50 \%$ dos pacientes obesos estudados. A obesidade causa hipertrofia ventricular excêntrica, relacionada ao aumento do volume sangüíneo circulante. Entretanto, em hipertensos obesos, ocorrem aumento da resistência vascular sistêmica e hipertrofia concêntrica do ventrículo esquerdo, aumentando os riscos de isquemia miocárdica durante manobras desencadeadoras de descargas adrenérgicas. A redução de peso resulta em melhora das dimensões ventriculares ${ }^{8}$ e em controle da hipertensão arterial ${ }^{9,10}$.

Distúrbios do metabolismo glicídico e lipídico são comuns em pacientes morbidamente obesos. A obesidade acompanha-se invariavelmente de resistência à insulina. Embora a lipemia de jejum possa ser normal em indivíduos obesos, hiperlipemia pós-prandial ocorre freqüentemente, provavelmente pela competição entre quilomicra e lipoproteínas de muito baixo peso molecular, pelas mesmas vias metabólicas. A obesidade causa superprodução de lipoproteínas de muito baixo peso molecular pelo aumento do influxo hepático de ácidos graxos livres, tanto no período pós-prandial (a partir da lipólise de partículas ricas em triglicerídeos), como durante os períodos pós-absortivos (a partir dos adipócitos) 11. Assim, justificam-se as prevalências de diabete melito tipo II e de dislipemia em $6,25 \%$ e em $20,83 \%$ dos pacientes obesos deste estudo. Ambas as condições são fatores de risco de aterosclerose e cardiopatia isquêmica e são controladas pela cirurgia bariátrica ${ }^{12}$

Hipotireoidismo sub-clínico ocorre mais freqüentemente em pacientes obesos e/ou diabéticos e pode ser responsável pela baixa taxa de gasto de energia em repouso encontrada em alguns pacientes obesos ${ }^{13,14}$.

A esteatose hepática não alcoólica ocorre freqüentemente em pacientes obesos e pode progredir para cirrose hepática e insuficiência hepática. O tratamento da obesidade melhora esta condição. Os fatores de risco mais fortemente associados são a resistência à insulina, hipertensão arterial sistêmi$\mathrm{ca}^{15}$. Neste estudo, a esteatose hepática foi diagnosticada, por ultra-sonografia pré-operatória, em 12,5\% dos pacientes. O reconhecimento desta condição deve direcionar a investigação para testes laboratoriais adicionais da função hepática, já que a farmacocinética dos anestésicos venosos e bloqueadores neuromusculares pode estar alterada na presença de comprometimento funcional do fígado. Além disto, o fígado esteatótico é mais suscetível ao dano hipóxico ${ }^{16}$.
Pacientes morbidamente obesos apresentam alterações nas provas de função pulmonar, caracterizadas por redução do volume expiratório de reserva, da capacidade vital forçada, do volume expiratório forçado em 1 segundo, da capacidade residual funcional e da ventilação voluntária máxima ${ }^{17}$. O trabalho respiratório está aumentado na obesidade. A presença de apnéia do sono agrava esta condição por causar redução da condutância respiratória nas vias aéreas superiores e inferiores, sobrecarregando os músculos da respiração ${ }^{18}$. Os anestésicos venosos e bloqueadores neuromusculares utilizados para a indução da anestesia provocam alterações na mecânica respiratória, principalmente aumento da resistência das vias aéreas, resultando em hipoxemia ${ }^{19}$. No paciente obeso, o aumento do volume de fechamento torna o tempo para a desnitrogenação alveolar mais longo e menor a tolerância à apnéia ${ }^{20}$.

Asma ocorre mais freqüentemente em pacientes obesos do que em não obesos, conforme demonstrado neste e em outros estudos ${ }^{21}$. É provável que o refluxo gastroesofágico seja um fator importante na etiopatogênese da asma em pacientes obesos. As cirurgias bariátricas controlam a gravidade da doença em $50 \%$ dos pacientes ${ }^{22}$. A asma associa-se a aumento do risco de broncoespasmo durante a intubação traqueal e medidas profiláticas estão justificadas.

Este estudo tem as limitações inerentes aos estudos retrospectivos do tipo caso-controle. Por exemplo, alguns problemas bem conhecidos do paciente obeso, como as anormalidades anatômicas da coluna vertebral e da via aérea superior não foram incluídos, porque não foram registradas no banco de dados consultado. Para a escolha do grupo controle, os pacientes foram relacionados segundo a idade, o sexo e o estado físico, com o objetivo de tornar semelhantes as características demográficas de ambos os grupos. Apesar disto, houve predomínio de pacientes do sexo feminino e do estado físico II, no grupo de pacientes morbidamente obesos. Isto se explica pelo fato de que não foi estabelecida uma relação fixa de pareamento entre os grupos, no tangente ao número de casos, ou seja, todos os pacientes com as mesmas características de cada paciente do grupo 1, constantes do banco de dados, foram incluídos no grupo controle.

Apesar destas limitações, o estudo revela os problemas clínicos mais freqüentemente associados à obesidade, no contexto da cirurgia bariátrica.

Conclui-se que, comparados a pacientes não obesos de mesma idade, sexo e estado físico, pacientes morbidamente obesos apresentam mais freqüentemente problemas clínicos pré-anestésicos. Recomenda-se que a consulta pré-anestésica ocorra com precocidade suficiente para permitir que exames laboratoriais adicionais e consultas especializadas sejam realizadas. 


\section{Preanesthetic Clinical Problems of Morbidly Obese Patients Submitted to Bariatric Surgery: Comparison with Non-Obese Patiens}

Getúlio Rodrigues de Oliveira Filho, TSA, M.D., Tânia Helena Carnieleto Nicolodi, M.D., Jorge Hamilton Soares Garcia, TSA, M.D., Marcos Antônio Nicolodi, TSA, M.D., Ranulfo Goldschmidt, TSA, M.D., Adilson José Dal Mago, M.D.

\section{INTRODUCTION}

Morbid obesity is defined by a high body mass index, that is, weight in kilos divided by the square of height in meters, equal to or higher than $40 \mathrm{~kg} \cdot \mathrm{m}^{-2}$. Its prevalence has increased in the last decades and, as a consequence, the cost with the treatment of associated diseases, such as hypertension, diabetes mellitus, ischemic heart disease and pulmonary artery hypertension have also increased. Life expectancy of morbidly obese patients is significantly lower as compared to their non-obese counterparts. For such patients, surgery is the only effective treatment ${ }^{1}$. The knowledge of obesity-related problems allows for a deeper investigation of systems more often affected by the disease during preanesthetic evaluation. This study aimed at identifying obesity-related diseases detected during preanesthetic evaluation in morbidly obese patients submitted to gastric bypass and at comparing their incidence in a non-obese population.

\section{METHODS}

After the Hospital's Medical Ethics Committee approval, preanesthetic evaluation records of 2.986 patients were reviewed. Patients were divided in Group $1(n=48)$ : morbidly obese, submitted to gastric bypass; and Group $2(n=2938)$ : with body mass index (BMI) below 30 and submitted to other elective procedures, who were matched to Group 1 patients by age, gender and ASA physical status. Preanesthetic problems identified in Group 1 were investigated in Group 2 and prevalences were compared by Chi-square test with Yates' correlation and Fisher's exact test. Odds ratio (OR) and respective $95 \%$ confidence limits (CL95\%) were calculated from respective contingency tables. Significance level was $5 \%$.

\section{RESULTS}

Groups were homogeneous in age and height. Frequency of physical status ASA II and female gender, as well as weight and BMI were significantly higher in Group 1 (Table I).
Table I - Demographic Data

\begin{tabular}{|c|c|c|}
\hline & Group 1 & Group 2 \\
\hline Age (years) ${ }^{1}$ & $36.36 \pm 12.58$ & $36.06 \pm 11.61$ \\
\hline Weight $(\mathrm{kg})^{1}$ & $120.70 \pm 19.98$ * & $65.37 \pm 8.81$ \\
\hline Height $(m)^{1}$ & $1.65 \pm 0.08$ & $1.66 \pm 0.08$ \\
\hline BMI $\left(\mathrm{kg} \cdot \mathrm{m}^{-2}\right)^{1}$ & $43.77 \pm 5.70$ * & $23.63 \pm 2.69$ \\
\hline Gender $(M / F)^{2}$ & $8 / 40$ * & $1674 / 1264$ \\
\hline $\operatorname{ASA}(I / I I)^{2}$ & $11 / 37$ * & $1329 / 1609$ \\
\hline
\end{tabular}

1. Data expressed by Mean \pm SD

2. Data expressed by frequency

${ }^{*} p<0.05$ between groups

Diseases identified during preanesthetic evaluation of Group 1 patients and also seen in Group 2, together with their respective prevalences, were: gastroesophageal reflux $(16.67 \%$ and $0.48 \%)$, systemic hypertension $(50 \%$ and $3.06 \%)$, type Il diabetes mellitus ( $6.25 \%$ and $0.31 \%)$, hypothyroidism $(6.25 \%$ and $0.31 \%)$, bronchial asthma $(10.42 \%$ and $1.43 \%)$ and restrictive lung disease $(10.42 \%$ and $0.03 \%)$ (Table II).

Table II - Clinical Problems: Comparison Between Groups

\begin{tabular}{|c|c|c|c|}
\hline Problem & Group 1 & Group 2 & OR $(C L 95 \%)^{2}$ \\
\hline Gastroesophageal reflux $(\mathrm{P} / \mathrm{A})^{1}$ & $8 / 40$ * & $14 / 1924$ & $\begin{array}{c}41.77 \\
(15.04 ; 113.93)\end{array}$ \\
\hline Arterial hypertension $(\mathrm{P} / \mathrm{A})^{1}$ & $24 / 24$ * & $90 / 2848$ & $\begin{array}{c}31.64 \\
(16.16 ; 60.32)\end{array}$ \\
\hline Type II Diabetes mellitus (P/A) ${ }^{1}$ & $3 / 45$ * & $9 / 2929$ & $\begin{array}{c}21.69 \\
(6.96 ; 91.47)\end{array}$ \\
\hline Hypothyroidism (P/A) $^{1}$ & $3 / 45$ * & $9 / 2929$ & $\begin{array}{c}21.69 \\
(6.96 ; 91.47)\end{array}$ \\
\hline Asthma (P/A) ${ }^{1}$ & $5 / 43$ * & $42 / 2896$ & $\begin{array}{c}8.01 \\
(2.64 ; 22.51)\end{array}$ \\
\hline Restrictive lung disease $(\mathrm{P} / \mathrm{A})$ & $5 / 43$ * & $1 / 2937$ & $\begin{array}{c}341 \\
(37.57 ; 759.31)\end{array}$ \\
\hline
\end{tabular}

1. $P / A=$ present $/$ absent; data expressed by frequency 2. OR $(C L 95 \%)=$ Odds Ratio $(95 \%$ Confidence Limit) $*=p<0.05$ between groups

The following problems were also identified in Group 1, but not seen in Group 2: epilepsy (2.08\%), nonalcoholic fatty liver (12.5\%), gall bladder stones (6.25\%), dyslipidemia $(20.83 \%)$ and hypopytuitarism $(2.08 \%)$.

\section{DISCUSSION}

Selection criteria for gastric bypass were established by the International Federation for Obesity Surgery and are the following: body mass index above $40 \mathrm{~kg} \cdot \mathrm{m}^{-2}$, or between 35 and $40 \mathrm{~kg} \cdot \mathrm{m}^{-2}$ in patients with co-morbidities treatable by weight loss, presence of obesity for at least 5 years, conservative treatment failure, no alcohol or severe psychiatric problems history, age between 18 and 55 years and acceptable surgical risk determined by preoperative evaluation ${ }^{1}$.

Obese patients candidates to obesity surgeries are submitted to a multidisciplinary evaluation including, nutritionists, specialized nurse, psychologist or psychiatrist and anesthesiologist. The anesthesiologist's role is critical for detecting Vol. 52, No 2, Março - Abril, 2002 
coexistent morbidities, recommending additional exams and specialized evaluations, aiming at controlling coexistent diseases. This is the reason why preanesthetic evaluation is performed well in advance.

In our study, the prevalence of gastroesophageal reflux was significantly higher in obese patients. While obesity could not contribute to the presence of gastroesophageal reflux ${ }^{2}$, there are evidences that weight and body mass index are directly related to this condition ${ }^{3}$, probably due to a higher incidence of hiatal hernia ${ }^{4}$. Manometric esophageal changes were observed in $61 \%$ of patients and may contribute for visceral sensation abnormalities in morbidly obese patients ${ }^{5}$. Patients with body mass index above $30 \mathrm{~kg} \cdot \mathrm{m}^{-2}$ had 2.8 times more chance of developing reflux (1.7 to 4.5 ) than those with BMI below $30 \mathrm{~kg} \cdot \mathrm{m}^{-2} 6$. The presence of gastroesophageal reflux is related to critical events associated to tracheal intubation ${ }^{7}$. Systemic hypertension was observed in $50 \%$ of obese patients. Obesity leads to eccentric ventricular hypertrophy related to the increase in circulating blood volume. However, in hypertensive obese patients there is an increase in systemic vascular resistance and left ventricle concentric hypertrophy, increasing the risk for myocardial ischemia during adrenergic discharge-triggering maneuvers. Weight loss results in improved ventricular dimensions ${ }^{8}$ and in hypertension control ${ }^{9,10}$.

Glicidic and lypidic metabolic changes are common in morbidly obese patients. Obesity is invariably followed by insulin resistance. Although fasting lipemia being normal in obese patients, post-prandial hyperlipemia is frequent, probably due to the competition of kilomicra and very low molecular weight lipoproteins for the same metabolic paths. Obesity leads to an overproduction of very low molecular weight lipoproteins by liver free fatty acids influx increase, both in post-prandial periods (as from lipolysis of triglyceride-rich particles) and during post-absorption periods (as from adipocytes) ${ }^{11}$. So, $6.25 \%$ prevalence of type II diabetes mellitus and $20.83 \%$ prevalence of dyslipemia in obese patients are justified. Both conditions are risk factors for arteriosclerosis and ischemic heart disease, and are controlled by gastric bypass ${ }^{12}$.

Sub-clinical hypothyroidism is more frequent in obese and/or diabetes patients and may be responsible for the low resting energy expenditure rate found in some obese patients ${ }^{13,14}$ Non-alcoholic fatty liver is frequent in obese patients and may evolve to liver cirrhosis and failure. Treating obesity will improve this condition. Most important risk factors are insulin resistance and systemic hypertension ${ }^{15}$. In our study, non-alcoholic fatty liver was diagnosed by preoperative ultrasound in $12.5 \%$ of patients. The diagnosis of such condition should direct the investigation to additional liver function lab tests since intravenous anesthetics and neuromuscular blockers pharmacokinetics may be changed in the presence of liver disfunction. In addition, the fatty liver is more susceptible to hypoxic damage ${ }^{16}$.

Morbidly obese patients have abnormal pulmonary function tests, characterized by decreased reserve expiratory volume, forced vital capacity, forced expiratory volume in 1 se- cond, functional residual capacity and maximum voluntary ventilation ${ }^{17}$. Respiratory work is increased with obesity. Sleep apnea worsens such condition for decreasing respiratory conductance in upper and lower airways, thus overloading breathing muscles ${ }^{18}$. Intravenous anesthetics and neuromuscular blockers used for inducing anesthesia change respiratory mechanics, especially by increasing airway resistance resulting in hypoxemia ${ }^{19}$. The increased closing volume of obese patients prolongs alveolar denitrogenation time and reduces apnea tolerance ${ }^{20}$.

Asthma is more frequent in obese, as compared to non-obese patients, as shown by this and other studies ${ }^{21}$. Gastroesophageal reflux might be an important factor in asthma patogenesis in obese patients. Gastric bypass controls disease severity in $50 \%$ of patients ${ }^{22}$. Asthma is associated to an increased risk for bronchospasm during tracheal intubation and prophylactic measures are justified.

This study has the limitations inherent to case-control retrospective studies. For example, some well-known obesity-related problems, such as spinal and upper airway anatomic abnormalities were not included because they were not recorded in the database. For choosing the control group, patients were recorded by age, gender and physical status, aiming at establishing similar demographics for both groups. In spite of that, there has been a predominance of females and physical status ASA II patients in the morbidly obese group. This is explained by the fact that no fixed relationship was established to match groups as to the number of cases, that is, all patients with the same characteristics of each group 1 patient were included in the control group.

Notwithstanding those limitations, the study has shown clinical problems most frequently associated to obesity in the context of gastric bypass.

The conclusion was that, when compared to non-obese patients of the same age, gender and physical status, morbidly obese patients had a higher prevalence of preanesthetic problems. It is recommended that the preanesthetic evaluation be done well in advance to allow for additional lab tests and specialized evaluations.

\section{REFERÊNCIAS - REFERENCES}

01. Baxter $\mathrm{J}$ - Obesity surgery - another unmet need: it is effective but prejudice is preventing its use. BMJ, 2000;321:523-524

02. Largergren J, Bergstrom R, Nyren O - No relation between body mass and gastro-esophageal reflux symptom in a Swedish population based study. Gut, 2000;47:26-29

03. Fisher BL, Pennathur A, Mutnick JL et al - Obesity correlates with gastroesophageal reflux. Dig Dis Sci, 1999;44:2290-2294

04. Wilson LJ, Ma W, Hirschowitz BI - Association of obesity with hiatal hernia and esophagitis. Am J Gastroenterol, 1999;94: 2840-2844

05. Jaffin BW, Knoepflmacher P, Greenstein R - High prevalence of asymptomatic esophageal motility disorders among morbidly obese patients. Obes Surg, 1999;9:390-395

06. Locke III GR, Talley NJ, Fett SL et al - Risk factors associated with symptoms of gastroesophageal reflux. Am J Med, 1999;106:642-649 
07. Chung F, Mezei G, Tong D - Pre-existing medical conditions as predictors of adverse events in day-case surgery. Br J Anaesth, 1999;83:262-270

08. Koch R, Sharma AM - Obesity and cardiovascular hemodynamic function. Curr Hypertens Rep, 1999;1:127-130

09. Bourdages $H$, Goldenberg F, Nguyen $P$ et al - Improvement in obesity-associated medical conditions following vertical banded gastroplasty and gastrointestinal bypass. Obes Surg, 1994;4:227-231

10. Abu-Abeid S, Keidar A, Szold A - Resolution of chronic medical conditions after laparoscopic adjustable silicone gastric banding for the treatment of morbid obesity in the elderly. Surg Endosc, 2001;15:132-134

11. Castro-Cabezas M, Halkes CJ, Erkelens DW - Obesity and free fatty acids: double trouble. Nutr Metab Cardiovasc Dis, 2001;11:134-142

12. Sjostrom CD, Peltonen M, Wedel $\mathrm{H}$ et al - Differentiated long-term effects of intentional weight loss on diabetes and hypertension. Hypertension, 2000;36:20-25

13. Proces S, Delgrange E, Vander-Borght TV et al - Minor alterations in thyroid-function associated with diabetes mellitus and obesity in outpatients without known thyroid illness. Acta Clin Belg, 2001;56:86-90

14. Tagliaferri M, Berselli ME, Calo $G$ et al - Subclinical hypothyroidism in obese patients: relation to resting energy expenditure, serum leptin, body composition, and lipid profile. Obes Res, 2001;9:196-201

15. Dixon JB, Bhathal PS, O'Brien PE - Nonalcoholic fatty liver disease: predictors of nonalcoholic steatohepatitis and liver fibrosis in the severely obese. Gastroenterology, 2001;121:91-100

16. Chitturi S, Farrel GC - Etiopathogenesis of nonalcoholic steatohepatitis. Sem Liver Dis, 2001;21:27-41

17. Biring MS, Lewis MI, Liu JT et al - Pulmonary physiologic changes of morbid obesity. Am J Med Sci, 1999;318:293-297

18. Zerah-Lancner F, Lofaso F, Coste A et al - Pulmonary function in obese snorers with and without sleep apnea syndrome. Am J Respir Crit Care Med, 1997;156:522-527

19. Pelosi P, Croci M, Ravagnan I et al - Respiratory system mechanics in sedated, paralyzed, morbidly obese patients. J Appl Physiol, 1997;82:811-818

20. Hakala K, Mustajoki P, Aittomaki J et al - Effect of weight loss and body position on pulmonary function and gas exchange abnormalities in morbid obesity. Int J Obes Relat Metab Disord, 1995;19:343-346
21. Dixon JB, Chapman L, O'Brien $P$ - Marked improvement in asthma after Lap-Band surgery for morbid obesity. Obes Surg, 1999;9:385-389

22. Dhabuwala A, Cannan RJ, Stubbs RS - Improvement in co-morbidities following weight loss from gastric bypass surgery. Obes Surg, 2000;10:428-435

\section{RESUMEN}

Oliveira Filho GR, Nicolodi THC, Garcia JHS, Nicolodi MA, Goldschmidt R, Dal Mago AJ - Problemas Clínicos Pré-Anestésicos de Pacientes Mórbidamente Obesos Sometidos a Cirugías Bariátricas: Comparación con Pacientes No Obesos

Justificativa y Objetivos - La obesidad mórbida se asocia a problemas clínicos, responsables por disminución de la expectativa de vida. Pacientes obesos mórbidos son candidatos a cirugías bariátricas, imponiendo nuevos desafíos al anestesiólogo. Este estudio comparó la prevalencia de problemas clínicos entre pacientes mórbidamente obesos sometidos a cirugías bariátricas y no obesos sometidos a otros procedimientos electivos.

Método - Fueron estudiados, retrospectivamente, los registros electrónicos de 2986 pacientes divididos en grupo 1, obesos mórbidos sometidos a cirugías bariátricas y grupo 2, con índice de masa corporal menor que 30, sometidos a otros procedimientos electivos, relacionados al grupo 1 por la edad, sexo y estado físico (ASA). Los problemas pré-anestésicos del grupo 1 fueron pesquisados en el grupo 2 y las prevalencias comparadas. Las razones de chance (RC) y respectivos limites de $95 \%$ de confianza (LC 95\%) fueron calculados.

Resultados - Los problemas identificados nos grupos 1 y 2 y sus respectivas prevalencias fueron: reflujo gastroesofágico $(16,67 \%$ y 0,48\%), hipertensión arterial sistémica $(50 \%$ y 3,06\%), diabetes mellitus tipo II (6,25\% y 0,31\%), hipotiroidismo (6,25\% y 0,31\%), asma bronquica $(10,42 \%$ y $1,43 \%)$ y pneumopatia restrictiva $(10,42 \%$ y $0,03 \%)$. Las prevalencias fueron significativamente mas altas en el grupo 1. Fueron también identificados, en el grupo 1, los siguientes problemas que no fueron encontrados en el grupo 2: epilepsia $(2,08 \%)$, esteatosis hepática $(12,5 \%)$, colecistopatia calculosa $(6,25 \%)$, dislipidemia (20,83\%) e hipopituitarismo (2,08\%).

Conclusiones - La prevalencia de problemas clínicos es significativamente mas alta en pacientes portadores de obesidad mórbida de que en no obesos de la misma edad, sexo y estado físico. 